\title{
Exposure screening of some aquatic animals to persistent pollutants on the Rhone river, France
}

\author{
L. Chantoiseau, H. Fenet ${ }^{1}$ and J. Bontoux
}

Département Sciences de l'Environnement et Santé Publique, UMR 5556, Faculté de Pharmacie, avenue Ch. Flahault, BP. 14491, 34093 Montpellier cedex 05, France

${ }^{1}$ Laboratoire de Chimie Analytique, Faculté de Pharmacie, avenue Ch. Flahault, BP. 14491, 34093 Montpellier cedex 05, France

\begin{abstract}
The Rhone river is contaminated with nuclear, chemical, urban and agricultural wastes. This study is an investigation of the level of exposure to polychlorinated biphenyls (PCBs), radionuclides of top predators of this river, Great cormorant (Phalacrocorax carbo sinensis) and European eel (Anguilla anguilla). Low concentrations of PCBs were found in liver and muscle of cormorants and eels from the Rhone river in 2000 and in $2001:$ the total PCBs contamination was about $2 \mu \mathrm{g} / \mathrm{g}$ lipid for both cormorants and eels from the Rhone river. All measurements of artificial radioactivity in cormorants from the Rhone river were below the detection limit. Two 7-ethoxyresorufin- $O$ deethylase (EROD) activity experiments on caged eels were conducted in the lower Rhone river. EROD activity was induced and could be correlated to persistent pollutants as PCBs or others dioxin-like pollutants, or polycyclic aromatic hydrocarbons (PAFs). These results suggest that cormorants and eels are at least, slightly contaminated with PCBs and not with artificial radionuclides, despite the high level of nuclearization of the valley.
\end{abstract}

\section{FRAMEWORK}

\subsection{Main line}

The Local Commission of Information (CLI) about energy equipment in Gard (France) and the Regional Direction of Industry and Research (DRIRE) of Languedoc-Roussillon (France) have initiated a reflection about the importance of the nuclear effluents released in the Rhone river, according to others polluting effluents. Lower valley of the Rhone river drains nuclear, chemical, agricultural and urban wastes. One ton per day of mineral and organic chemicals is released in the river. Organic pollutants are about $750 \mathrm{~kg}$ per day [1]. Pollutants in lower Rhone are most often pesticides (atrazine, simazine and lindane), solvants (toluene, phenolic derived) and aromatic pollutants (polychlorinated biphenyls (PCBs), polycyclic aromatic hydrocarbons (PAHs)). PCBs are ubiquitous contaminants in the environment, although their use has been strongly restricted in France since 1976. PCBs concentration in lower Rhone water are greater than those in higher Rhone water, with respectively $20 \mathrm{ng} / \mathrm{L}$ and $5 \mathrm{ng} / \mathrm{L}$. But the source of this local waste is not identified [1]. Moreover, Rhone is the most nuclearized river in the world. Each of the nine nuclear sites (figure 1) reject, in the river and in the atmosphere, artificial radionuclides $\left(\mathrm{H}^{3}, \mathrm{Am}^{241}, \mathrm{Be}^{7}, \mathrm{Co}^{60}\right.$, $\mathrm{Co}^{58}, \mathrm{Cs}^{134}, \mathrm{Cs}^{137}$ ) in accordance with the authorized limits. Then, by the time, fauna and flora from the Rhone river could bioaccumulate these pollutants, known to be promotor in carcinogenesis.

A significant exposure to PCBs and artificial radionuclides could occur in Great cormorant ( $P$. carbo) and European eel (A. anguilla) because of their top predator position in the food chain, and the contact of eels with sediments.

The purpose of the CLI and DRIRE work is to obtain quantitative and qualitative information about background levels of artificial radionuclides and PCBs in these two species of the lower Rhone ecosystem. Radioactive analyses concern the most common released artificial radionuclides by nuclear plants $\left(\mathrm{Ag}^{110 \mathrm{~m}}, \mathrm{Am}^{241}, \mathrm{Be}^{7}, \mathrm{Co}^{60}, \mathrm{Co}^{58}, \mathrm{Cs}^{134}, \mathrm{Cs}^{137}, \mathrm{Eu}^{154}, \mathrm{Mn}^{54}, \mathrm{Na}^{22}, \mathrm{Rh}^{106}, \mathrm{Sb}^{124}, \mathrm{Sb}^{125}, \mathrm{Ac}^{238}, \mathrm{Th}^{234}\right.$ and $\mathrm{Pb}^{210}$ ). PCBs analyses concern the twelve congeners PCB-28, 52, 77, 101, 105, 118, 126, 128, 138 , 153.169, and 180. In addition, in order to complete the exposure assessment in European eel, EROD 
activity was measured, during two caging experiments in the Lower Rhone river, upstream and downstream the effluent of a chemical industry still using PCBs. The use of both eel and cormorant in the monitoring of two anthropogenic kinds of pollutants, as radioactivity and PCBs, simultaneously is an unexplored procedure in the Rhone river.

\subsection{Sampling}

Cormorants (Ph. Carbo sinensis) is most of the time migratory fish-eating bird, even if more and more they choose now to colonize French freshwaters during the whole year. Cormorants spend the winter period at the exact same place year by year [2,3]. Birds were collected in January 2000 (campaign A) and January 2001 (campaign B) during the annual regulation shoots, authorized by the French Environment Minister. The cormorants were sampled on the Rhone river (figure 1), downstream the release of most effluents near Camargue's delta (polluted site), and upstream most industries, near Lake of Geneva (reference site).

European eel is a common fish in the Rhone. It stands as an eurhyhaline and migratory species, but is sedentary for a long time (about 9-15 years) in such freshwater [4]. Local eel fishing on the Rhone river, at the same site as the one chosen for cormorants, supply us with fishes. Eels were also captured in a Mediterranean coastal lagoon (reference site), which has no connection with Rhone river.
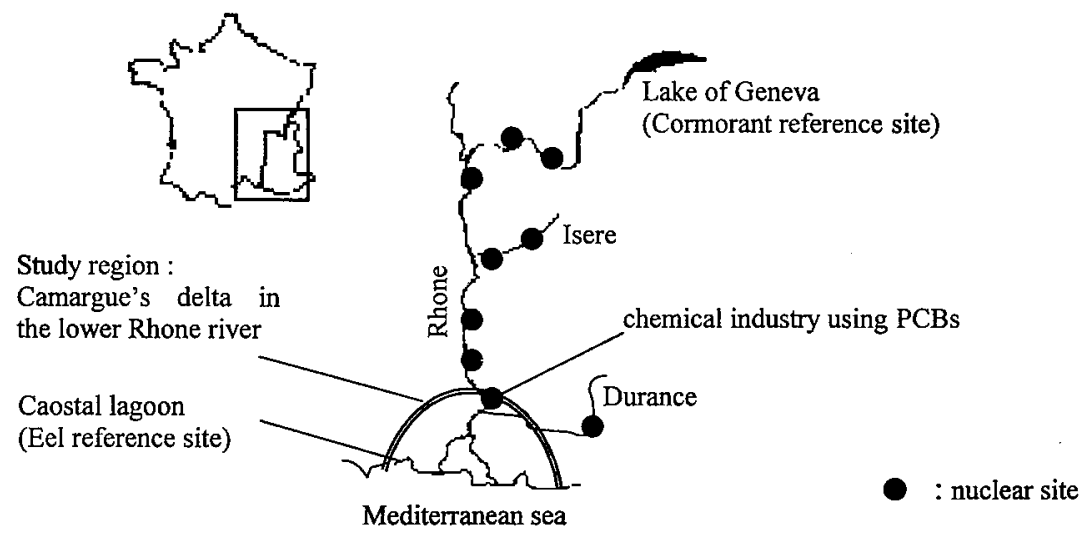

$50 \mathrm{~km}$

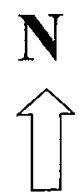

Figure 1 : Study region setting along the Rhone river, France : the lower Rhone river is the polluted site, the coastal lagoon is the reference site for eels, Lake Geneva is the reference site for cormorants.

\subsection{Methods of analyses}

The chemical determination of PCB contamination [5] was conducted on 20-30 g portions of muscle and liver for each animal. The homogenized portion was extracted twice with organic solvents (1:1 acetone/petroleum ether; 1:1 petroleum ether/diethylether), using an accelerator solvent extractor (UltraTurrax $®, 13000 \mathrm{rpm}, 5 \mathrm{~min}$.). The organic extracts were washed by ultra-pure water with sodium chloride, to remove hydrophile pollutants, and dried with anhydrous $\mathrm{Na}_{2} \mathrm{SO}_{4}$. Then, the collected organic extracts were concentrated by using a rotavapor $(B)$ at $40^{\circ} \mathrm{C}$ under vacuum. A florisil $(3)(50-100$ mesh from Alltech) chromatography cartridge was used to purify the final extract. PCB analyses were performed on a gas-chromatograph connected to a mass spectrometric detector [6]. 
Others samples weighing about $15-50 \mathrm{~g}$ were dried and finely ground. Gamma spectrometry of artificial and natural radionuclides series was performed. The detector used was a very low resolution high performance apparatus, with a very low background antiCompton, to minimize detection limits.

Induction of ethoxyresorufin- $O$-deethylase (EROD) during caging experiment - where the time and the site of exposure are defined - have been reported for assessing PCBs exposure on fishes [6-11]. The sites selected for the eel caging experiment were in the lower Rhone river, upstream and downstream an industrial site using PCBs (figure 1). The eels were coming from the reference site.

\section{RESULTS}

\subsection{PCBs congeners}

For campaign $\mathrm{A}$ and $\mathrm{B}$, the $\mathrm{PCBs}$ concentrations in reference cormorants (Geneva) and reference eels (lagoon) were founded under or equivalent to the limit of quantification $(0.005 \mu \mathrm{g} / \mathrm{g}$ lipid for cormorants and $0.001 \mu \mathrm{g} / \mathrm{g}$ lipid for eels) [6].

For the two campaigns, cormorants and eels collected in the Rhone river showed for PCB-153, PCB138, PCB-180, PCB-118 and PCB-101 concentrations above limit of quantification (table 1). The concentrations of all other congeners were under or equivalent to the limit of quantification. In the Rhone river cormorants, the PCB profile (table 1) was made of PCB-153, PCB-138 and PCB-180 were prevalent, and to a less extent PCB-101 and PCB-118. The PCB profile (table 1) for eels from the Rhone river is near the precedent : it shows a prevalence of PCB-153, PCB-138 and PCB-101. These profiles are similar to those met in European cormorants and eels $[6,12]$.

Table 1 : Campaign A (n) of January 2000 and campaign B (n) of January 2001 PCBs results ( $\mu$ g/g lipid) in Rhone river eels and cormorants.

\begin{tabular}{|c|c|c|c|c|c|c|c|}
\hline & e & $\begin{array}{c}\text { PCB-101 } \\
\mathrm{x} \pm \text { sd } \\
\text { [range] }\end{array}$ & $\begin{array}{c}\text { PCB-118 } \\
\mathrm{x} \pm \mathrm{sd} \\
\text { [range] }\end{array}$ & $\begin{array}{c}\text { PCB-138 } \\
\mathrm{x} \pm \mathrm{sd} \\
\text { [range] }\end{array}$ & $\begin{array}{c}\text { PCB-153 } \\
\mathrm{x} \pm \mathrm{sd} \\
\text { [range] }\end{array}$ & $\begin{array}{c}\text { PCB-180 } \\
x \pm \text { sd } \\
\text { [range] }\end{array}$ & $\begin{array}{c}\text { Total PCBs } \\
\mathrm{x} \pm \mathrm{sd} \\
\text { [range] }\end{array}$ \\
\hline $\begin{array}{l}\text { Rhone } \\
\text { cormorants }\end{array}$ & $\begin{array}{c}\text { Campaign A } \\
\text { (13) } \\
\text { Campaign B } \\
(10) \\
\end{array}$ & $\begin{array}{c}0.10 \pm 0.10 \\
{[0.013-0.27]} \\
0.21 \pm 0.16 \\
{[0.030-0.45]}\end{array}$ & $\begin{array}{c}0.28 \pm 0.26 \\
{[0.043-0.49]} \\
0.28 \pm 0.068 \\
{[0.16-0.40]}\end{array}$ & $\begin{array}{c}0.60 \pm 0.50 \\
{[0.046-1.67]} \\
0.43 \pm 0.31 \\
{[0.021-0.86]}\end{array}$ & $\begin{array}{c}0.57 \pm 0.79 \\
{[0.012-2.92]} \\
0.68 \pm 0.33 \\
{[0.091-1.48]} \\
\end{array}$ & $\begin{array}{c}0.53 \pm 0.64 \\
{[0.023-1.50]} \\
0.30 \pm 0.25 \\
{[0.010-0.53]} \\
\end{array}$ & $\begin{array}{c}1.98 \pm 1.26 \\
{[0.83-2.60]} \\
1.84 \pm 1.34 \\
{[0.078-3.08]} \\
\end{array}$ \\
\hline Phone eels & $\begin{array}{c}\text { Campaign } A \\
(8) \\
\text { Campaign B } \\
(8) \\
\end{array}$ & $\begin{array}{c}0.29 \pm 0.25 \\
{[0.017-0.64]} \\
0.13 \pm 0.071 \\
{[0.047-0.25]}\end{array}$ & $\begin{array}{c}0.048 \pm 0.048 \\
{[0.0068-0.13]} \\
0.076 \pm 0.031 \\
{[0.025-0.11]}\end{array}$ & $\begin{array}{c}0.39 \pm 0.61 \\
{[0.034-1.63]} \\
0.31 \pm 0.14 \\
{[0.087-0.47]} \\
\end{array}$ & $\begin{array}{c}1.00 \pm 1.40 \\
{[0.18-4.16]} \\
0.69 \pm 0.27 \\
{[0.21-0.96]} \\
\end{array}$ & $\begin{array}{c}0.149 \pm 0.137 \\
{[0.033-0.26]} \\
0.22 \pm 0.16 \\
{[0.027-0.45]} \\
\end{array}$ & $\begin{array}{c}1.88 \pm \mathbf{2 . 4 2} \\
{[0.96-7.40]} \\
1.44 \pm 0.56 \\
{[0.40-2.09]}\end{array}$ \\
\hline
\end{tabular}

\subsection{Radioactivity}

With respect to artificial radioactivity, all measurements were below the detection limit. Only gamma natural radionuclide analyses (as $40 \mathrm{~K}$ ) were above limit of detection.

\subsection{EROD activity}

The results of the two eels caging experiments (figure 2) abound in the direction of a contamination of the lower Rhone water by persistent pollutants as PCBs, but also others dioxin-like pollutants or HAPs... 


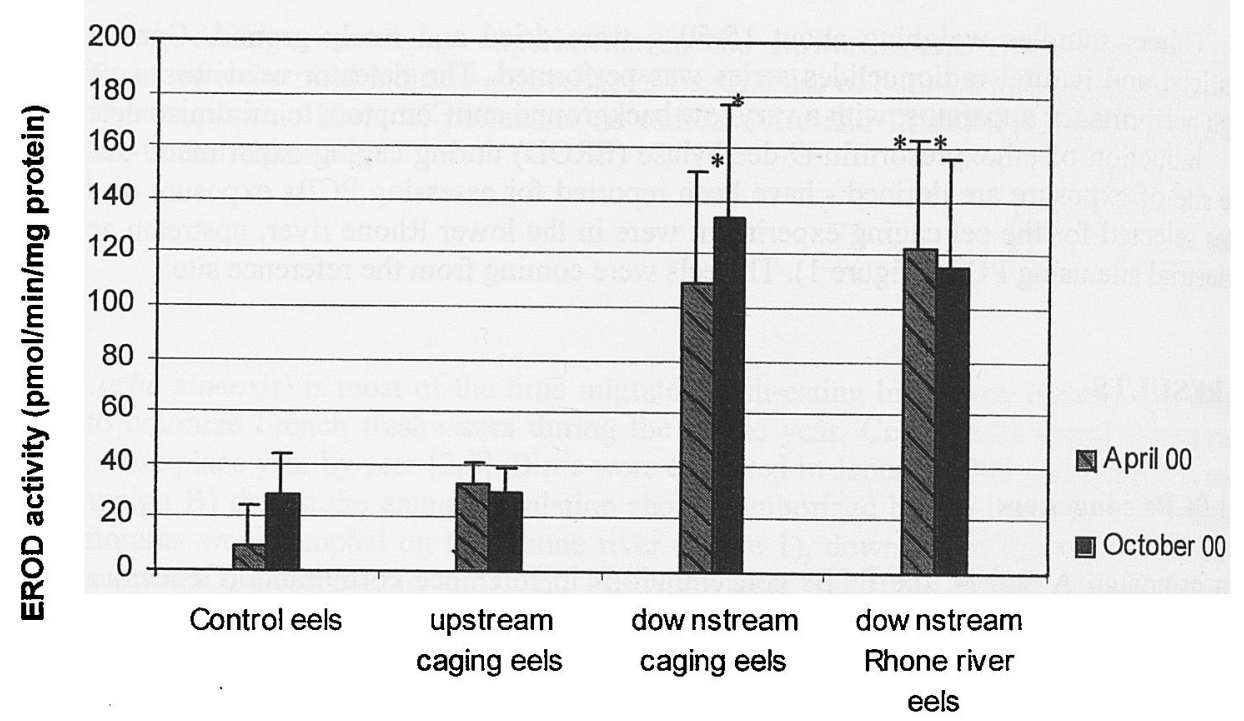

Figure 2 : EROD activities in April and October 2000 in Lower Rhone river eels. Control = eels acclimated in the laboratory, upstream caging = eels caged upstream the chemical runoff, downstream caging = eels caged downstream the chemical runoff, downstream Rhone $=$ eels of the lower Rhone river. Means $+/$ - SE. $n=8$. T-test values; ${ }^{*} \mathrm{p}<0.01$, compared with upstream.

\section{CONCLUSION AND PERSPECTIVES}

Lower Rhone river cormorants and eels are slightly contaminated with PCBs. Others organisms as Nutrias (Nutria nutria) which live in contact with sediments, should be interesting to analyze because of their high exposure to pollutants. These animals could be very highly exposed to PCBs or to artificial radioactivity [6].

Even if the Rhone river is the most nuclearized river in the world, no radioactive bioaccumulation was observed in this study.

This first approach has pushed us to carry out broader investigations which include other biomarkers as well as pollutant analysis in order to meet the needs of multiparametric investigations. Further studies should focus in details on the possible synergistic effects at low environmental concentration, in order to assess the trend of a potential threat to the future of the species.

\section{Acknowledgments}

The authors would like to thank the Direction Régionale de l'Industrie et de la Recherche and the Commission Locale d'Information du Gard, for financial support, and Institut de Protection et de Sûreté Nucléaire for technical support.

Gratitude is also extended at MM. Barbier, Fontaine, Gerdeaux, Guillard, Laboureau and Salvador for technical support in collecting eels and cormorants.

\section{References}

[1] French Water Agency, Qualité des eaux du Rhône, évolution 1969-1995 (1999).

[2] Lebreton, J-D. and Gerdeaux, D., Gestion des populations de Grand Cormoran Phalacrocorax carbo séjournant en France (report CEFE - INRA - Ministère de l'Environnement, 1996). 
[3] Fédération des Associations Cévenoles Environnement Nature (FACEN), Opération Grands Cormorans, suivi du Grand Cormoran (Phalacrocorax carbo sinensis) sur les Gardons : effectif et prédation (1999).

[4] Roche, H., Buet, A., Jonot, O. and Ramade, F., Organochlorine residues in European eel (Anguilla anguilla) crucian carp (Carassius carassius) and catfish (Ictalarus nebulosus) from Vaccarès laggon (French National Nature Reserve of Camargue) - effects on some physiological parameters. Aqu. Toxicol., 48 (2000) 443-459.

[5] Berset, J.-D. and Holzer, R., Determination of Coplanar and Orthosubstituted PCB in Some Sewage Sludges of Switzerland using HRGC/ECD and HRGC/MSD. Chemos. 32, 12, (1996) 2317-2333.

[6] Chantoiseau, L., Les polychlorures biphényles : implication dans le risque écologique, Thèse d'exercice, Faculté de Pharmacie de Montpellier (2000), 83 p.

[7] Fenet, H., Casellas, C. and Bontoux, J., Hepatic enzymatic activities of the European eel Anguilla anguilla as a tool for biomonitoring freshwater stream : laboratory and field caging studies. Wat. Sci. and Tech., 33, 6 (1996) 321-329.

[8] Hewitt, S., Fenet, H. and Casellas, C., Induction of EROD activities in European Eel (Anguilla anguilla) by different Polychlorobiphenyls (PCBs), Wat. Sci. Tech., 38, 7, (1998) 245-252.

[9] Flammarion, P, Migeon, B. and Garric, J., Joint effects of copper sulfate and methidathion on rainbow trout (Oncorhynchus mykiss) EROD and AchE activities. Bull. Envirn. Contam. Toxol. 56, (1996) 440445 .

[10] Bernhoft, A., Hektoen, H., Skaare, J. and Ingebrigtsen, A., Tissue Distribution and Effects on Hepatic Xenobiotic Metabolising enzymes of 2,3,3',4,4'-Pentachlorobiphenyl (PCB-105) in cod (Gadus morhua) and Rainbow Trout (Oncorhynchus mykiss). Environ. Poll., 85 (1994) 351-359.

[11] Melancon, M., Development of Cytochromes P450 in Avian Species as a biomarker for Environmental Contaminant Exposure and Effet: Procedures and Baseline Values. Environmental Toxicology and Risk Assessment : Biomarkers and Risk Assessment (American Society for Testing and Materials, David A. Bengtson and Diane S. Henshel, Eds., Fifth Volume, ASTM STP 1306, 1996).

[12] Borlakoglu, J., Wilkins, J., Walker, C. and Dils, R., 1990. Polychlorinated Biphenyls (PCBs) in FishEating Birds - II. Molecular Features of PCBs Isomers and congeners in adipose tissue of Male and Female Puffins (Fratercula artica), Guillemots (Uria aalga), Shags (Phalacrocorax aristotelis) and Cormorants (Phalacrocorax carbo) of British and Irish coastal waters. Comp. Biochem. Physiol., 97C, (1), 161-171. 